\title{
Cultural Trauma of the Civil War of 1918 Staged and Commemorated in Finland
}

\section{PENTTI PAAVOLAINEN}

\begin{abstract}
:
The Centennial of one of the cruelest of European civil wars fought in Finland between the Reds and the Whites from January to May 1918 has evoked a spectrum of theatre productions illustrating variations of styles and approaches on the events. The turn in the treatment of this cultural trauma occurred with the interpretations and narrative perspectives that were fixed in the 1960s, when an understanding for the defeated Red side was expressed in historiography, literature and theatre. Since that, the last six decades the Finnish theatre and public discourse on the Civil War have been dominated by the Red narrative as the memory of the 1918 Civil War provided an important part in the new identity politics for the 1969 generation. Since the 1980's the topic was mostly put aside so that before the 2018 revivals of the Civil War topic, the productions seem to have been reactions by the artists confronting the developments at the end of the Cold War. Some theatrical events can even be tied to the cultural trauma of the 1969 left evoked by the collapse of the socialist block. The Centennial productions repeated the Red narrative but they also provided more balanced interpretations on the tragic events.
\end{abstract}

\section{KEYWORDS}

Civil War, Finland 1918, Revolution in Finland, War of Independence in Finland, War representations in theatre, political narratives in theatre, cultural trauma, Piotr Sztompka, trauma processes, trauma treatment, national reconciliation, identity, Cold War, labour movement, the jaeger movement, historiography 


\section{Cultural Trauma of the Civil War of 1918 Staged and Commemorated in Finland}

The Centennial of one of the cruelest of European civil wars fought in Finland from January to May 1918 has given rise to a spectrum of theatre productions illustrating a variety of styles and approaches to the events. The events were referred to as Revolution or Rebellion by the socialist Reds and a Liberation War or War of Independence by the bourgeois Whites. ${ }^{1}$ An artistic treatment of the events from both sides was limited during the 1920s and 1930s and the new image of the Civil War in novel, theatre and film was gradually revised only from late 1940s onwards and extensively since 2000.

The essential turnabout occurred with a change in the interpretations and narrative perspectives that were fixed in the 1960s, when the modern historical research began and an understanding of the defeated side was expressed in literature and theatre. Since then, during the last six decades, the Finnish theatre and public discourse on the Civil War has been dominated by what can be called the Red narrative. In the 1980s the topic was mostly sidelined until a new wave emerged around the centennial year 2018. But as the memory of the 1918 Civil War had provided an important part in the identity of the 1969 generation, it is argued that before 2018 the revivals of the Civil War topics in theatre were also political reactions confronting the developments at the end of the Cold War. Some can even be tied to the cultural trauma of the left evoked by the collapse of the socialist block.

\section{CULTURAL TRAUMA AS A CONSTRUCTION}

The concept of cultural trauma was proposed by the Polish sociologist Piotr Sztompka (2000) in an influential article, ${ }^{2}$ subtitled "The Other Face of Social Change" which was well informed about the historical developments of the twentieth century from Eastern and Middle European perspectives. According to Sztompka, the description of social change needed renewed conceptualization in order to make understandable what was taking place in Europe around the Millennium.

1 Cf. Tepora \& Roselius 2014; https://encyclopedia.1914-1918-online.net/article/finnish_civil_ war 1918; https://en.wikipedia.org/wiki/Finnish Civil War is well based on recent scholarship.

2 Sztompka 2000. The theory was developed in an anthology by Alexander Jeffrey C. et al. 2004. 
Following the discourses of progress of the modern era and the discourses of crisis of the same modern developments we have witnessed manifold discourses around trauma, which emerged in Europe since the 1980s when the undermined atrocities and forgotten ethnic violations invaded the public sphere during the Gorbachevian glasnost ("openness"), both in the Soviet and in its satellites. The holocaust has been acknowledged and publicly condemned since 1945, but not the wide and equally systematic Gulag-network. The refugee problems of the 1940s and the brutalities on both sides of the Eastern front were waiting for objective recoveries, repressively hidden for decades. Millions of people had met with - in Sztompka's words - "sudden, radical, deep, unexpected, mostly external, horrifying changes in their cultural environment". ${ }^{3}$ These events and the experiences of several generations of Europeans ought to be recognised and theorized as they were buried deep both in the cultural undercurrents, and in the daily politics since 1989. Cultural trauma may be caused by unveiling the truth about some element of the past, which had been collectively denied or falsified. Consequently, the new revisionist interpretation of adopted national traditions or some other mythical traditions like the 'class struggle', can be traumatic.

The first one applies without saying to the experiences of 1918 Finland and the latter somewhat modified to the crises of the world view of the Western 1969 'progressive generation'. And it was their presuppositions and landmarks that had to be rethought at least by 1991 , at the end of the Cold War. ${ }^{4}$

Jeffrey C. Alexander (2012) subsequently theorized the concept of trauma from the constructivist viewpoint. Although it is difficult to deny any actual participant the occurrence of traumatic events as such, but even so the events have been identified and told by some social actors within the process. ${ }^{5}$ The events have become defined and formulated as representational narratives. These trauma narratives for the most part have their carrier groups, the collective agents in the trauma process but also, those who make the claim for the narrative to be heard. Down the line, a renewed Trauma-story must appeal to the audience, "persuaded that they too have become traumatized by an experience or an event, [which] the [new] carrier group needs to engage in successful meaning making work." ${ }^{6}$

\section{THE FINNISH CIVIL WAR AND ITS TRAUMATIC EVENTS}

The Civil War of 1918 can be considered a most harsh cultural (political and social) trauma in Finland both for the Reds and the Whites, although the number of the casualties and the executed were unequal: at least three times the number if not

3 Sztompka 2000, 452.

4 Tepora \& Roselius (eds.) 2014 arrange their chapters on the Civil War legacy in periods, while there is little written on generations. The two dominant turns can be found first in the beginning of the cold war and the other at the end of the cold war. Somewhat modified, they are also markers in this article: the early 1960s is the most important turning point in the theatrical treatment of the War but the end of the Cold War is not as clearly visible in theatre as in other legacies.

5 Alexander Jeffrey C. 2012, 17. He continues in warning of the naturalistic fallacy, which tends to take the sufferings as such and omits the processes around the formulation of the experiences and the discourses.

6 Alexander 2012, 17. 
more were Reds due to the severe punishments carried out by the White troops during their victorious periods. ${ }^{7}$

The background and context lay in the economic collapse and the revolutions in Russia in 1917, which caused a vacuum of power in its Western region, the autonomous Grand Duchy of Finland. The unequal social structure of the class society was confronted by several developments: a worsening economic situation, the lack of authoritative order, the founding of armed forces by Reds and by Whites, an insufficiency of work and the increasing food prices, as well as a radicalization of the youngest generation of the social democrats. ${ }^{8}$ This process was met by a goading from Lenin to start an immediate revolution in Finland, which then happened at the end of January 1918. Formally, it was a rebellion by the radical socialists against the legitimate government of the independent republic acknowledged by the Council of People's Comissars in St Petersburg only one month earlier. The Finnish government found its support in the bourgeois majority of the parliament as well as the in the rural population.

Until April 1918, The People's Delegation of Finland, i.e. the Red government and the Red guards, controlled Southern Finland. The Northern parts remained loyal to the White government, which operated from Vaasa with a conscripted peasant army led by General C. G. Mannerheim, former servant of the Russian Empire. The lower ranking officers of the army consisted of those volunteers (jaegers) who returned from receiving military training in Germany (1915-1918) and who had dreamt of one day creating a liberation army for Finland.

For the White army the seizure of Tampere, the industry capital, became the first target. The battle of Tampere at the end of March lasted for a week, and was the largest urban war action in Northern Europe: it moved from house to house; wood-houses burning, stone-house windows used as machine guns positions, until the Reds surrendered and were imprisoned en masse on 3 April 1918. The White victory was secured by the landing of the German Baltic Sea Division on the Southern coast and their advances which culminated in the liberation of Helsinki on 11 April 1918. Lenin's support and his hands were tied by the Brest-Litovsk peace treaty, according to which all Russian forces should be withdrawn from Finland by 1 March 1918.

The catastrophe for the Reds since the fall of their stronghold Tampere escalated to an immense tragedy with escaping crowds of the armed guards and unarmed

7 With highly debated and much written topics like the Finnish Civil War, the peer control tends to qualify the wikipedia-articles. Therefore, adjacent reading on the events can be recommended. This page is well informed about the recent scholarship, the formulations are balanced and sources indicated: https://en.wikipedia.org/wiki/Finnish_Civil_War. Lavery, 2006 is for instance an overall concise political history of Finland.

8 In the one house Parliament (with the equal participation of both sexes) since 1907, the Social Democrats was the largest party, which joined the liberal bourgeois parties in proposing many reforms. They were however blocked by the moderate conservatives and the Tsar. He even would dismiss the Diet if it proposed something too radical. By 1917 ten years of work in the Parliament without results in the most important issues had frustrated the SDP supporters. Such were the equal communal census and the 8-hour working day. After Kerenski's fall in late autumn of 1917 both of these were decreed under the bourgeois majority and the bourgeois government (senate). But then the radicals now urged by Lenin and the Bolsheviks rather trusted on a revolution (coup d'état) than the parliamentary principle - which is one of the aspects in the tragedy that followed. 
civilians towards the east. The punishments by the winners in occupied villages and towns were cruel; field shootings and even mass murders took place in AprilMay 1918, approximately 5.000-10.000 Reds were shot after battles or executed following court martials. Some 80.000 prisoners became a huge problem for the victors from May 1918 onwards. The State Treason Courts began work in June and their interrogations (78.000 cases) were based on the premise that the leaders would get longer sentences than the ordinary followers. ${ }^{9}$ Lenin had offered refuge only for the hastily escaped Red leaders, while their originally moderate followers died in thousands in Finland. This was not least due to a starvation catastrophe and the pandemic Spanish flu raging in the prison camps during the summer of 1918. ${ }^{10}$

After the collapse of the German Empire in October 1918, the political development in Finland was rapid. Mannerheim was anti-German, but pro White Russia: his relationships made it possible to ally with the victorious Entente, and to promote the normalization of political life. It was time for the rise of the moderate Social Democrats, for the anti-violence majority of the workers' movement to restart their political activity. Larger amnesties of the Red prisoners had been already put into effect by December 1918. But at the same time a general amnesty was decreed for the White war crimes. This imbalance was probably needed in order to avoid a series of trials for the members of the small elite within the new weak state and its fresh army. Yet this left a strong bitterness on the Red side and created a deep silence on the White side. ${ }^{11}$

The communal elections held in January 1919 gave the Social Democrats finally their great number of voices in the municipal councils and in two months the parliamentary election of March 1919 the SDP regained its position as the largest party winning 80 of 200 seats. In the first presidential election in July 1919 , a moderate conciliatory candidate K. J. Ståhlberg was elected with a clear majority and the postponed reformist legislation was immediately revived. But as the anti-bolshevist White Russian Committee was unwilling to guarantee any future independence for Finland, the government refused to give support to the Whites in the Russian Civil War (1918-1922). ${ }^{12}$

Despite the recovery of political participation, the bourgeois mistrust continued: the Red refugees in the Soviet-Russia had organized themselves as the Finnish Communist Party. Their explicit aim was for revenge, a new revolution in Finland, which would have meant a reinclusion of the young republic into Russia as a part of the Soviet realm. ${ }^{13}$ The communists infiltrated the underground in Finland and founded the party to the left of SDP which was called SSTP. ${ }^{14}$ Like elsewhere in Europe the military circles reacted to the "unfinished counter-revolution", which rooted many of the fascist movements. Also in Finland the aftermath culminated in

9 Tikka 2014, 104-115. Cf. also 'The Finnish Civil War' in Wikipedia.en; or Sotasurmat in narc.fi.

10 Tikka 2014, 112-118.

11 Extensively on the aftermath in Tepora \& Roselius 2014.

12 Roselius 2014, 143.

13 This is hardly to be doubted in the light of the recent scholarship. Cf. Lackman 2017. Kinnunen 2014, 424 considers this argument yet as a part of the War of Liberation discourse.

14 Saarela 2014, 331-339. 
1930-1932 with a threat of a rightwing coup d'état. ${ }^{15}$ It was unsuccessful, however, and the moderate parliamentarian line came to dominate also the bourgeois faction. Political rights for the communists in Finland were ensured only in 1945 and since then they have obtained their proportionate seats in the Parliament. Unlike many of its southern neighbours, Finland succeeded in avoiding any dictatorship during the twentieth century.

As late as the 1960s, two projects of relevant academic scholarship emerged. Tuomo Polvinen published his Venäjän vallankumous ja Suomi 1917-1920 [The Russian Revolution and Finland 1917-1920.] (I \& II: 1967 \& 1971) where the geopolitical context were precisely illuminated. The other influential and pioneering work was that by Jaakko Paavolainen who was the first to document the statistics, including the names of those murdered and executed, i.e. revealing the true scope of the terror of the two sides plus the mortality in the prison camps. ${ }^{16}$ By 2018 , the historiography of the Civil War had become substantial and has had effect on the country, including the theatre makers. ${ }^{17}$

\section{CULTURAL TRAUMA AND THEATRE}

Theatre as a public political forum has offered powerful emotional and intellectual encounters for remembering, and a platform from which to collectively work through cross-generational memories and a means to develop their narratives. ${ }^{18}$ In the Finnish theatre all the productions dealing with the Civil War have usually received deserved attention. No scholarly overview of the treatment of the topic however has yet emerged. ${ }^{19}$

Drawing from the Sztompka's (2000) and Alexander's $(2004,2012)$ contributions to the concept of cultural trauma, this article will suggest examples of how some of the performances were participating in either overcoming the trauma or reviving the trauma in new political contexts. In their view, time alters the external context and causes inevitable generational shifts within the traumatised individuals. Both processes will contribute to the gradual lessening of the trauma symptoms. Theatre can participate in the overcoming of the trauma by suggesting ways of getting along, living with the trauma and healing its scars. It may propose ways of seeing the old trauma in the new political conditions. In Finland the idea of reconciliation was often an articulated purpose and surfaces in many art works

15 The recent European research on the birth of fascism links it mostly to the frustrations of the White resulting in World War I. (Silvennoinen \& Roselius \& Tikka 2016). See also Roselius 2014 b. 16 Propagandistic horror legends could no more be recycled after the publishing of Punainen terrori [The Red Terror] (1966); Valkoinen terrori [The White Terror] (1967), Vankileirit Suomessa 1918 [The Prisoncamps in Finland in 1918] (1971). J. Paavolainen's card indexes have formed the base for the present public database "War Victims in Finland 1914-1922." https://sotasurmat.narc. fi/victims/faceted-search/table?page=0 (narc.fi). See also Tepora \& Roselius 2014b, 9-10.

17 The scholarship has dealt with the context of the Russian and German developments, with the role of Lenin in the outbreak of the war, with the role of female guards, with the role of children and the fates of the Red orphans, plus several well qualified local histories. A relevant summary of these discussions in Tepora \& Roselius 2014b. 9-16.

18 Paavolainen 1992 discusses extensively theatre as a social forum for dealing with non-explicit concerns of a community.

19 Tepora 2014b and Kinnunen 2014 look at literature and films but omit theatre and drama. 
but the terms may be questioned: reconciliation yes, but whose explanation formulates the agenda. ${ }^{20}$

These processes are not one way. Theatre may revive a trauma by repeating a victim's narrative, and so it can recruit new generations to adopt an inherited trauma-identity. Such processes may be adopted by a following generation in a new political constellation or for a revived political purpose. In this manner theatre may work against the oblivion, against a politically motivated forgetting: "the memory of the martyrs must be kept alive!" For some segments of the society, theatre may thus lead to empowerment and constructive elements of identity. It can even offer a locus of nostalgia for an imagined good old time, be it even a class struggle.

This article will observe some occurrences of these functions in relation to the Civil War dramas on stages in Finland, trying to keep in mind that the memories of a historical process in its stage versions are not as innocent as a simple trauma recovery or an articulated "wish for reconciliation" would suggest. ${ }^{21}$

\section{FIRST 40 YEARS: DOMINATION OF THE WHITE NARRATIVE}

After the Civil War the workers' houses were first confiscated. Gradually in 1919 their activities were allowed to be recovered if run by the moderate wing workers. There was no ongoing censorship, but the police could interrupt and prevent performances if they offended the state law or encouraged armed rebellion. This happened to some of the first Red dramas, written by authors close to the radicals. ${ }^{22}$ They remained single incidents on the Red side.

The treatment of trauma in the 1920s workers' theatres can be perceived in the work ofthe German expressionist Ernst Toller, who held a special position in their repertories. Toller discussed the unsuccessful German Spartacist Revolution (1918) by writing a drama on the Luddite uprisings (1811-1813) articulated in Die Maschinenstürmer (The Machine Wreckers) which resulted in seven Finnish productions. The masses were agitated and urged by a false leader to take arms without understanding the unbalance of the power-structures. The play ends with soldiers executing workers backstage. In Tampere this drama was seen only five years after the real bullets sounded not far from the workers' house. ${ }^{23}$

20 Tepora 2014b discusses the reconciliation suggested in Jarl Hemmer's novel as one happening in bourgeois terms. The roles, which theatre and drama seem to be playing constantly in dealing with cultural trauma are many. We can show examples where theatre may really "break a silence" by providing a first opportunity to discuss a sensitive issue in public. It may be explicit or metaphoric, and happen through adherent narratives or other disguises, even via minor characters of the play. The question is, however, how objective or balanced the given interpretation is experienced. Does it give equal voices to conflict partners, do they speak on their own agency in the drama?

21 Comments will be related to Tepora 2014b and Kinnunen 2014.

22 The general information on plays and their performances has been gathered from several standard sources. One is the Database ILONA by The Finnish Theatre Information Centre (www. ilona.tinfo.fi). - A complete list can be found at the end of this article. Seppälä 2010, 150-151 \& 305-308 records: Verneri Jokiruoho's Veljesvihaa [Fraternal hate] (1921) and Voitetut sankarit [Defeated heroes] (1922); Unto Kekäläinen's Valkoinen kosto [White revenge] (1921) as well as Sovittamattomat [The irreconcilables] (1922) by Kaarlo Valli.

23 Paavolainen 2005. 
In addition, Ernst Toller created a character of the working man hemmed in by the 1922 inflation and unemployment and totally deprived of self-esteem: Eugen Hinkemann had lost his genitals in the war. The tragedy Hinkemann was seen in eleven productions - with always a profound audience response from the workers' theatres in Finland. ${ }^{24}$ These Toller examples demonstrate that an effective treatment of a trauma does not need any literal verisimilitude on stage, "the structure of feeling" is enough. To apply Raymond Williams' classical concept: the locus of empathy in the drama must be recognizable and felt immediate in light of the experiences within the community. ${ }^{25}$

The trauma on the White side was the rebellion itself, understood as treason by the Reds after two decades of political work (1898-1917) for the common aim, to defend the autonomy of Finland against the Russian government. What was traumatic was all the harshness that the logic of war forced on the bourgeoisie and the patriotic youth supporting their national aims to act in anger and achieve what they were driven to accomplish. And which they would have wished later to be undone. ${ }^{26}$

On the White side, the events during the Civil War itself were remembered in war reports. On the stage it was more inspiring however to recall the times of the twilight, moments when independence was only a dream, not the painfully achieved goal which brought with it a traumatic tragedy of guilt in the accomplishment of the dream. This limitation informed those plays which chronicle the Jaeger-movement, which were staged on the fifth ${ }^{27}$ and fifteenth ${ }^{28}$ anniversaries of the victory. In general, the Finnish military glory could be projected through a domestic historical drama located in Germany of the Thirty Years' War. ${ }^{29}$

But the real jubilee-musical, an intrigue-comedy with soldiers, spies, songs and dances, came in 1921. Sam Sihvo's Jääkärin morsian [The Jaeger's bride] in the Finnish National Theatre (SKT). This musical comedy was set in 1916 Liepaja (Libau), present day Latvia, the town where the jaegers received military training. The Jaeger's bride was filmed twice (in 1931 \& 1938) and was an ongoing success in theatres until 1944, with some later reruns. It enjoyed a longer life than any other of the works of those decades.

Two Swedish-writing authors were able to sharpen their eyes and pens on the topic with good dramas and dramatizable novels. Their reception was not easy but they have spoken to later generations. The most qualified writer was

24 Paavolainen 2005. Toller was not unknown in the young Soviet Russia, cf. Spalek 1968.

25 Raymond Williams, the father figure in the Cultural Studies, introduced the concept in his writings on theatre.

26 The future president Urho Kekkonen (1900-1986) had attended the shootings on the White side. His large political program gradually turned to become the "unification of the Finns".

27 Such was the White melodrama of 1923 by IImari Kianto: Hallan jääkärit [The Jaegers in Halla], in which the recruited students adventurously escaped by the Northern routes via Sweden to Germany. They were persecuted by the tsar's police forces. (Rajala 2018, 258.)

28 The $15^{\text {th }}$ anniversary in 1933 provided a White account by Risto Kuusi (pseudon.): Jääkärit [The Jaegers] playing tribute to the story of the independence fighters, ending with their victorious return. With very few dramatic merits, it served as a historical tableau in the White Finland of the time and has not been revived.

29 In the Finnish and Swedish speaking bourgeois theatres the victory in May 1918 was often celebrated with a classical play about an episode involving the Finns and Swedes in the Thirty Years War (1618-1648). The play was Z. Topelius' Regina von Emmeritz. See Paavolainen 2015. 
Runar Schildt who in his novel Hemkomsten [Homecoming] in 1919, depicted a mother who gives shelter to her Red son who escapes the White revenge his own brother and father are on the White side. In 1923 Schildt made a major contribution to the early drama. The protagonist of his play Den stora rollen [The Great Role] is an actor of second rank, who now, in 1918 gets an opportunity once "to play a major part in real life-theatre" as a revolutionary leader, a protagonist in his own life, with tragic consequences of course. ${ }^{30}$

A strong individual voice came in the playscript by another writer in Swedish, Jarl Hemmer. For the tenth anniversary, 1928 Hemmer came up with a playscript Gehenna och ljusstrålen [Gehenna and the beams of light]. It was not performed understandably as the subject treated a young idealist priest who after the Whites' victory parade in Helsinki has to serve the large camp of Red prisoners on the Sveaborg Fortress Island [fi. Suomenlinna] outside Helsinki. He rewrote it as a novel: En man och hans samvete 1931; [A Man and his Conscience]. This text was the first to be filmed on the topic, only in 1957 but titled as "1918". Despite its strong melodramatic and religious tones, it was the first film to include enacted scenes of the prison-camps.

The Finnish author Lauri Haarla was very productive during the 1920s. He chose historical or mythological contexts for his expressionistic style dramas and treated questions of Über-Mensch, guilt, treason, violence, generations and power. He had fought on the White side although he had had socialist sympathies in his youth. Political close-reading of Haarla's dramas has yet to be realized. ${ }^{31}$ His Kaksiteräinen miekka [Double-edged sword] in 1932 was an attempt through diverse characters to describe developments before the outbreak of the Civil War: three sons from a worker's family and their neighbour, a working girl have to choose their sides. The play ends with the victory of the Whites and the meeting of the White and Red brothers. In the chaotic events the escaping Red girl is shot on the street. ${ }^{32}$ The author says he had aimed to evoke some understanding of the Red narrative in the sliding towards the conflict. A note about this is given in Haarla's complaint to his publisher that "the closer I come to the Spring 1918, the less I can find response from the [White] audiences: this generation will never reconcile [with the Reds]." ${ }^{33}$

Hella Wuolijoki, the well-known leftist intellectual preferred to idealise the Red cause in her Laki ja järjestys [Law and order] (1933), which was banned by the police, due to its "too partial look at the White cause". ${ }^{34}$ Yet Wuolijoki has her merits in gradually opening the discussion. In 1940 her guest Bertolt Brecht created his Herr Puntila und sein Knecht Matti on material provided by Wuolijoki. The relationship between Puntila and Matti and with the worker's family Surkkala can

30 Several leaders of the Red troupes had been amateur actors or directors, which was an interesting paradox. See Ylikangas 1993, 54 on Hugo Salmela. Jalmari Parikka and Aarne Orjatsalo are other names in this category.

31 Kalemaa 2012 writes a double biography of Lauri Haarla and his brother Rafael Haarla, an industrialist who supported the right-wing radicals. Jenny Lilja's dissertation (1979) looks at expressionist stylistic features avoiding all political readings.

32 Koskimies 1972, 304. It was performed only 8 times. See also Erkki Kivijärvi in Helsingin Sanomat 31.12.1932.

33 Quoted in Kalemaa 2012, 162.

34 cf. Koski 2000, 61-66. 
only be explained through the Civil War experiences. The prison camps become explicit in one of the stories by the "brides of Puntila". ${ }^{35}$

In the fourth drama in Wuolijoki's Niskavuori-cycle, Niskavuoren Heta [Heta of Niskavuori] (1952) there are two episodes, which take place during the Civil War. The daughter of the landowning peasant-family Heta supports the Whites, but her husband Akusti, although now a wealthy man, was born as a farm hand. He still enjoys the sympathies of the local Reds, mostly farm workers themselves. At least this tension was clearly articulated in this very popular drama, played around the country.

\section{THE RED NARRATIVE ENTERS THE STAGE}

In 1959 a factory worker and a successful novelist Väinö Linna ${ }^{36}$ began to publish his trilogy on the history of the tenantfamily Koskela over several generations, ranging from the 1880 s to the 1950s. The title is taken from the melancholic folk song "Here under the North Star, we still have our homeland..."37. The First Part of Täällä Pohjantähden alla [Here Under the North Star] -trilogy was greeted as a new socially and historically informed prose work although the notion of using an omniscient narrator was considered very traditional. The Second Part came out in 1960 following the perspective of the imagined parish south of Tampere. This part contained the developments that led to the Civil War, it related how the three Koskela brothers joined the Red guard and how two of them were finally executed and the eldest doomed to prison camp for some years.

Linna's perspective was limited logically to the perspective of his characters, and although he was criticized by some historians, the novel became a landmark in constructing a version of history that was both Red and rural. The version was somewhat fatalistic and it unquestionably victimized the Reds. This version of the events earned at that time a justified place among the public narratives. ${ }^{38}$

The North Star immediately found its way onto all the Finnish stages. The Tampere Workers' Theatre (TTT) celebrated its $60^{\text {th }}$ anniversary by staging Part Two in 1961, in a version by Eugen Terttula: Täällä Pohjantähden alla II [Here under the North Star II]. It was welcomed as a performance depicting grievous shock and evoked sympathies for the fate of the Reds., especially in the scene in the prison camp, performed in theatre for the first time. North Star I/ was presented in twenty two theatres (in 1962, 1963, 1964, 1965, 1967, 1968) and by 1971 it had enjoyed 360 performances in the country. The number is remarkable. ${ }^{39}$

35 Cf. the story is about an old wife who brings food to the prison camp and is not allowed to deliver her wrapped bread. The Finnish version Iso-Heikkilän isäntä ja hänen renkinsä Kalle by Wuolijoki was performed in 1954.

36 Linna's Unknown Soldier (1954) described a machine-gun platoon in the Continuation War (1941-1944). It was an unprecedented success and the first "grass-root" novel on the war time experiences, widely admired.

37 The poem is by A. J. Granlund and expresses the yearning over "our other homeland", the heaven.

38 The Third Part (1962) brought the story then over the five years of wars until 1950s, when the first generation of the Koskela-family and their neighbours pass away. But Linna's narrator had shown those opportunities, which the ameliorating life in Finland gradually was giving to these small farmers and their children.

39 Paavolainen 1992, 153-157. 
The trilogy has been filmed twice; in 1968 and in 2010. Director Ralf Långbacka in the Närpes summer theatre on the west coast produced Swedish speaking productions $(1966,1968,1977)$ which invited many spectators from Sweden, and inspired a whole decade of Arbetarspel [Workers' Plays] in which class struggle histories at the local level were presented. They were promoted by the Social Democratic organisations of the communities. ${ }^{40}$

The overall image is clear: the fatalism embodied in Linna's novel was replicated for decades: the peaceful farm hands' society based on idealistic grounds built their workers' houses until their children's generation became more radical in their grievances wanting societal security and reforms to guarantee their future life conditions. The Reds of Pentinkulma are depicted as innocent, without any responsibility or doubts about the beginning of the 1918 revolution, or the rebellion they were later accused of. It had just been their duty to join the movement - they were simply the victims. In Linna's narrative, even the terror by the Reds, like the shooting of a local baron, came from outside by an armed "flying Red patrol". For Linna, the most tragic person was the old pacifistic tailor Halme, the idealistic first founder of the workers' society, who amongst others, was executed.

Linna's vision was very appropriate - and soothing or healing for the generation of children and grandchildren of those Reds that had been there in 1918. There was no place for emotional attachment or understanding for those whose ancestors had been on the White side. Neither does Linna problematize the responsibility of the Red leaders for the outbreak of the war. For the generation of 1969 this was a very welcome new locus of identity, so that the left segment easily adopted the role of a victim 'slaughtered' by a White soldier. ${ }^{41}$ Throughout the 1970 s the Red narrative was perceived more sympathetically as it was seen to be on the side of the weak. It was also in line with the people's front governments of the time. There were many other occasions for re-interpretations of the Finnish history in the theatre of the 1970s. ${ }^{42}$ One of these influential performances was to be Homecoming by Runar Schildt. ${ }^{43}$

40 Långbacka (2011, 206 \& 211) tells about the visit of Arne Anderson from Sweden, who in 1974 in Närpes saw a production about an event in 1932 called "Horse strike". Back home Anderson wrote and directed Spelet om Norbergstrejken (1978), a large local history performance of a miners' strike in 1891-1892 in Norberg. Several subsequent 'bygdespel', local plays were performed in the following years, mostly connected to the social-democratic organisations. This information is gathered on the years (1981-1985) when the author worked as a dramaturge for the Finnish Association of the Workers' Theatres (TNL) and the contacts were regular over the sea.

41 The image of slaughter was revived through the reuse of the enemy word "lahtari" (Sw. slaktare), used by the Reds in 1918 for the Whites. - The growing dominance of the Red viewpoint is also observed by Tepora (2014b, 388.) - It was somewhat problematic for the new left that it was, however, an unsuccessful revolution.

42 Fresh interpretations of Finnish history emerged in a cycle of episodic plays by Lauri Sipari performed in the Summer Theatre on the Sveaborg Islands. The first concentrated on the political development from 1918-1919. This was called Suomen kuningas (1970), [The King of Finland], in which the bourgeois initiative of electing a German prince to the throne of Finland was ridiculed. Sipari's later plays also carried elements of the Red narratives throughout different episodes in twentieth century Finnish history. Lehtonen 2018.

43 In an adaptation by Johan Bargum, it was first performed in 1975 in the Lilla Teatern in Helsinki (Hemkomsten), before being translated and performed in several theatres in Finnish (Kotiinpaluu) 1975, 1976, 1977, 1979. 
For many, the White narrative seemed to have been silenced during the 1970s. One who reacted was the aged journalist and writer IImari Turja, a friend of the president Urho Kekkonen, who also as a youth of 18 had fought on the White side. ${ }^{44}$ Turja wrote his play Jääkäri Ståhl [Jaeger Ståhl] (1979) as an account of the jaeger-movement. Turja's play discussed the meagre conditions and the German military discipline met by these Finnish adventurers. It was staged in three theatres, and was of course well received by those elderly audiences, who yearned to see a positive or understanding and sympathetic version of the White side in the Civil War. ${ }^{45}$ Yet Turja followed the White tradition in which the actual war events and their consequences were not presented within the play.

Jaeger Ståhl fulfilled its task by giving voice to the bourgeois people, who had been annoyed by the public discussion in Finland, which in the 1970s was uncritical of any problems in totalitarian system and too quickly politely adopted Soviet-inspired revisions in the Finnish historiography. Turja's play has not been revived since 1980.

\section{THE CANONISATION OF THE RED NARRATIVE}

The influence of Linna can be underscored by listing the years of further adaptations and productions of the North Star: 1977, 1978, 1979 [KOM], 1989 [Lahti], 1992 [Pyynikki], 2002, 2006 [KOM], 2007, 2008, 2011, 2017. ${ }^{46}$ Some of their contexts will be discussed in detail.

But the most interesting tragic topic of the Civil War remained unwritten. There were first drafts written by the talented poet Pentti Saarikoski, who had recently excelled in small scale dramas. For him the protagonist of the tragedy would have been one of the Red leaders, Edvard Gylling. He was an idealist and an economist (PhD), who by invitation from Lenin moved over to develop the Soviet-Carelia 1920-1935, but who despite of, or because of his merits, died in Stalin's ethnic cleansings. ${ }^{47}$ Gylling would have personified the true tragedy of the educated Red idealists and the Red refugees behind the Eastern border.

Analysing the changing contexts of the North Star-productions, we notice that one of them surfaced in February 1979 at the time when the leftist movement of the students and hard liner artists began to fade and was contested. Most pathetic revolutionary or pro Soviet discourse was ridiculed by the next generation, whose sympathies were intellectually liberal and greenish, and who had mostly a pragmatic relationship with capitalism. The 1979 production of the North Star was in KOM-

44 The "re-unification" of the nation was his guiding principle as the cure of his own trauma of the Civil War. In the context of 1960s \& 1970s Kekkonen supported the young cultural radicals, who on their side opposed their own bourgeois fathers by adopting Kekkonen as their "new father". Kekkonen's policy of "trust and friendship with Soviet Union" was still considered unpatriotic by the traditional right wingers.

45 Ilmari Turja's Jääkäri Ståhl was performed 69 times in Vaasa, 35 in Kouvola and 80 in the Finnish National Theatre, 184 in all, which was a considerable success, actually 'a silent manifest by the audience'.

46 TINFO database ILONA

47 The poet Pentti Saarikoski (1937-1983) had an ongoing plan and some scenes written, although it was never accomplished due to his heavy misuse of alcohol. Cf. Tarkka 2003, 625 and Långbacka 2011, 395. 
teatteri, the left wing avant-garde group of the decade - this version by their small ensemble concentrated on the "political awakening" of Akseli Koskela and ended on his return home from the prison camp. The production was dramaturgically more concentrated than those previously staged. ${ }^{48}$

The opening performance was staged only one month before the parliamentary election of 1979 and was performed a lot of times. Becoming a part of the political campaign, it was mostly a confirmatory ritual for the ideology and identity of the left, not least for the loyal audiences of the ten year old KOM-teatteri. But it was also therapeutic for its audiences, as the new trauma experienced the left was the suddenly diminished support for their ideas. ${ }^{49}$

The new political power structure in the 1980s provides the best explanation as to why the Civil War remained absent from the stages for a whole decade. It was time to create a balance with the interpretations of history in times when the socialistic states already seemed to be on their way to their unavoidable bankruptcy. The Social Democrats (SDP) remained the biggest political party in Finland and for by and large two decade, the SDP had led the government. However, those who repeatedly $(1979,1982)$ won the elections were the bourgeois, who were not taken into the government until 1987 when the Coalition party became the Prime Minister's party. During the 1980s the far-left parties (Communists \& People's Democrats) were fractioned and their attractivity declined - not least due to the ongoing Kremlin sclerosis.

The glasnost ("openness") policy of Mikhail Gorbachev (1985-1991) finally made it easier to publicly question the ideological legends, ${ }^{50}$ and clearly articulate the contrafactual conclusion: if the Reds had won in 1918, Finland would have de facto been annexed and become a Soviet vassal state. This had been one of the key arguments in the debates about how the Civil War should be understood. ${ }^{51}$

In the green and bourgeois political landscape, with the increasing appreciation of the achievements of the Winter War (1939-1940) and the Continuation War (1941-1944), and with the diminishing attraction of socialist ideas, only one production of the North Star trilogy was made: in April 1989 in Lahti City Theatre under the leadership of director Raija-Sinikka Rantala, on the eve of 1 May.

Rantala's adaptation merged the three parts into one five hour evening with two intermissions. The scope was more collective, although it was based on the dichotomy of the two worlds, the Whites and the Reds who gradually glided into collision. This production was made for a "Finland which does not remember its history" as a progressive journalist wanted to interpret the context. ${ }^{52}$ For the Director Rantala herself, the production inevitably was an empowering process following a decade of political backlashes from the left, and the fall of the Berlin wall only six months later. The production went very well (eighty eight performances until 1991, which also indicates how much the large audiences had "missed" their

48 Ollikainen \& Tanskanen (eds.) 2013, 173-180.

49 The parliamentary elections of 1979 gave a clear victory to the right-wing Coalition-party.

50 Also, the developments in Poland and Estonia in the 1980s were followed with sympathy by the Finnish citizens, although the state leadership for long time continued its cautious diplomacy with SU.

51 Kinnunen 2014 presents the Post-Cold War discourses on this topic.

52 Kirsikka Moring in Helsingin Sanomat 30.4.1989. 
familiar narrative which allowed them to identify with the victim in times of this major political turnabout. ${ }^{53}$ The old Väinö Linna received a standing ovation.

The Lahti theatre house stood not far from those real Fellman's fields where the great escaping Red convoy was stopped at the end of April 1918 and 22.000 people imprisoned. In 1978 a fine commemorative group of statues had been installed on the Field. During those three seasons the Lahti North Star production was performed, The Berlin Wall fell, and two years later the Soviet Union was transformed into Russia - the narrative of the Finnish Civil War could not remain the same.

\section{FRACTURES IN THE RED NARRATIVE}

The Post-Cold War period was the important landmark in the debates on the Civil War-described as a period when the old White narrative gained new support and informed, for example, the discussions and the 1993 official festivities of the $75^{\text {th }}$ commemorational year. ${ }^{54}$ It was as if the final defeat of communism had been witnessed and therefore the legitimization of the War of Independence narrative of the right could be promoted without question.

But in the theatre during the 1990s it did not progress that quickly. We only see some partly sceptical interpretations of the Red narrative, which came unexpectedly from the previous leading figure of the progressive left theatre, the respected director Kalle Holmberg.

Holmberg began his first productions of Linna by directing the first part of North Star -trilogy, titled Akseli ja Elina on the revolving outdoor theatre of Tampere (Pyynikki summer theatre) for the summers of 1993 and $1994 .{ }^{55}$ The second half, now named Pohjantähden alla came in $1995 .{ }^{56}$ This latter part of the dramatization included the Civil War, followed by the imprisonment of Akseli but it also gave space for the life and reconciliatory sentiments of the characters of mature age during the late 1930s. It concluded with the funerals of the young men of the parish, casualties of the Winter War. ${ }^{57}$ By ending with this strong reconciliatory patriotic image, Holmberg validated the two decades of the reconciliation process, which in the real world resulted in the unanimous defence by the Finnish Reds and Whites against Stalin's military invasion in 1939. This process was and still is the "miracle of miracles" in the history of Finland. ${ }^{58}$ During the 1990 s no other theatre staged the North Star.

The next winter 1996, Holmberg remained rooted in the year 1918 by staging The Great Role by Runar Schildt in the Finnish National Theatre. The performance was very critical of the main character Armas Fager, a second rank actor, who always wanted to play the role of Cyrano, whowas a hero even on the battlefield.

53 Kirsikka Moring, HS 30.4.1989. On the adjacent page you can read important essays by Esa Adrian and Johannes Salminen on the ongoing Russian re-evaluation of Lenin and the history of the revolutions and the detecting of the prohibited literature.

54 Kinnunen 2014, 408ff.

55 Jukka Kajava, Helsingin Sanomat 20.6.1993.

56 Jukka Kajava, Helsingin Sanomat 20.6.1995.

57 Väinö Linna's novel the Unknown soldier (1955), had a protagonist who came from the same Koskela family. By continuing to direct the Unknown Soldier in 1997 for the Pyynikki summer theatre, Holmberg completed his cycle of the early twentieth-century Finnish history.

58 This sentiment is not a novelty. It had been used by Jaakko Paavolainen in 1967 at the end of his White Terror. 
Fager took the leadership in the Red revolution but quickly escaped like a street dog. In Schildt's play there is nothing heroic in this want-to-be leader, who finally strives for his panache. Was Holmberg also holding a critical mirror to himself as a leader figure of the 1969ers? The Swedish Theatre also made its homage in 2001 to this classical play, Den stora rollen by Schildt.

An even more influential dismantling of the heroically Red narrative came with Holmberg's next production in 1996 on the Tampere Workers' Theatre big stage. The dramaturgy by Harri Virtanen and Ritva Holmberg was based on the recent work by the historian Heikki Ylikangas. ${ }^{59}$ Tie Tampereelle (1993) [The Road of Tampere] was performed fifty two times. The Yugoslavian Wars were now taking place in Europe and the everyday brutality of warfare could not be overlooked.

Interestingly, the major scholarly contribution by Prof. Ylikangas was accused of "tearing the wounds open again", and once again the question of the White guilt was under public discussion, although it was crystal clear that the "present day independent democratic Finland would not have been possible without the White victory". ${ }^{60}$ But if Ylikangas' book does not hide the White war atrocities prior to the local courts and prison camps, its new aspect was the miserable leadership of the Reds, the lack of trained commanders, chaotic infrastructure and lack of reliable information from the fronts. The Red operations were uncoordinated and the drunken untrained troupes were not willing to march to the front line. In addition, some accidents such as an explosion in the Red headquarters and the desperate attempt to save the money and gold of the Reds with the help of a convoy through the White siege lines over frozen lakes, in order to continue the class-struggle elsewhere, sealed the Red defeat in Tampere.

Kalle Holmberg's The Road of Tampere looked at the war in Tampere, and followed Ylikangas it quoted many local texts and memoirs about the conditions in Tampere at the end of March 1918. So, there was nothing heroic in the performance, even a sense of resignation: not least because of the extensive use of the authentic diary of a school-rector, whose observations from the streets were incontrovertibly sharp. The production may even be seen as a farewell to Holmberg's youth, a kind of melancholic view of the 1969 rebellions. ${ }^{61}$

\section{THE NOSTALGIC ASPIRATIONS OF THE 1990S}

Despite the return of the White narrative in the public sphere, there was ground for political nostalgia for socialistic ideals among the students and artists. The mourning process for the lost ideals in the post-cold war era created some new trauma-reactions. But they can also be seen as reactions against the growing silence around the Red narrative. ${ }^{62}$

59 Helsingin Sanomat 6.9.1996 contains the review by Jukka Kajava and an essay by Jaakko Anhava on the problems of guilt.

60 Anhava 1996. Formally the aim of the Red Finland was the augmented Finland where the Russian Karelia would have been annexed to Finland, as remarked on also by Lavery 2006, 87. Neither did the Finnish Reds prefer a dictatorship and total annexation to Russia; but it is highly doubtful whether the Soviet influence could have been avoided, or how.

61 For this interpretation the author is indebted to Hanna-Leena Helavuori, who made many indepth interviews with Kalle Holmberg possible. Holmberg passed away in 2016.

62 Observed by Kinnunen 2014, $413 \mathrm{ff}$, who calls it antagonistic to the War of Liberation discourse and gives the title: "Remembering the Class Antagonism and Suffering of the Reds." 
The young author, philosopher and director Esa Kirkkopelto effected handshakes between the mournful students and the late middle-aged equally mournful leftists. At the Helsinki Student Theatre he made productions, which discussed the collapse of the different stages of Revolutions, like Pontikkatehdas (1992) [The Forest Distillery] in Soviet Karelia and Mahnovitshina (1992) in Ukraine, ${ }^{63}$ plus some other productions which allowed the "leftist's sorrow" to occur. Some of that nostalgia animated also the 1998 Turku City Theatre production of Ilpo Tuomarila's play Hennalan torvisoittokunta [Hennala brass band], yet with much more sarcasm. ${ }^{64}$ The positive collective agency in the village and a strong nostalgic aspect were explicit again in Pekka Milonoff's second version (2006) of the North Star in KOM in the Suomenlinna Summer Theatre. His son, an actor and the next leader of the group, played Akseli Koskela the male protagonist. ${ }^{65}$

The turn of the century inspired several authors of the next generation to deal with Civil War topics mostly sympathetic to the Reds and many works also produced stage and film versions. The constantly ongoing academic research had produced much detailed information and close analyses of several local events and individual biographies.

In novels and in theatre, we can read attention to individual ethics, ${ }^{66}$ ambivalent sexualities, ${ }^{67}$ or a balancing between upper and lower classes. ${ }^{68}$ Two of the novels were filmed. A third film Raja 1918 [The Border in 1918] in 2007 was based on authentic diaries of a young commandant who had to stabilize the traffic over the newly established state border between Finland and the Soviet Russia. The sense of authenticity of the complicated tensions gives this film a special unbiased quality. ${ }^{69}$ The approach of the $90^{\text {th }}$ anniversary of the Civil War has inspired many artists and writers and a hope for a recognised reconciliation clearly evoked some performances (in $2007^{70}$ and $2008^{71}$ ) that wished to achieve this.

63 The first one discussed the figure of Edvard Gylling the second one that of Nestor Mahno.

64 Tuomarila's wife Katariina Lahti, a GDR trained director produced it. A worker's brass band from Turku marches out to participate in the revolution only to find themselves at the prison camp of Hennala, in Lahti together with thousands of women and children.

65 Ollikainen \& Tanskanen 2013, $420-425,430$.

66 This was clearly in focus in the first stage interpretation (2000) of the previously (1957) filmed text from 1931 by Jarl Hemmer En man och hans samvete (SvT) in adaptation by Joachim Groth, with the leading role by his brother Marcus Groth.

67 Leena Lander's (2003) Käsky [The Command] was adapted on stage in 2006. Its theme though was more the tensions between sexes and male sexualities.

68 Kjell Westö's Helsinki novel Där vi en gång gått [Where We Once Walked] 2006 aimed to describe people from both sides, but only partially succeeded and was not without critical voices. Its stage version came in 2008.

69 Director Lauri Törhönen and the script by Aleksi Bardy worked on the diaries of the producer Jörn Donner's father, Kai Donner, who had been commandant at the border in 1918-1919.

70 In Tampere some Christian communities wanted to create a variant of a Church Opera, to celebrate the centennial of the Tampere cathedral. Tytti Issakainen's Vihan päivät 1918 [Days of hatred 1918.] (2007), embodied a culminating episode when a group of civilian refugees looked for asylum in the Tampere St. John's Church, today Tampere Cathedral. The forgiving and Christian mercy was advocated, although the point of the Red cause - according to some did not appear clearly enough. The script by Tytti Issakainen framed somewhat problematically the events in the present day. See Lauri Meri, Helsingin Sanomat 25.3.2007; Toni Lehtinen, Turun Sanomat 25.3.2007.

71 Kinnunen 2014, 436. Another commemorative event was arranged in Tampere on the occasion of the $90^{\text {th }}$ memorial of the battle of Tampere in early April 2008. 
The largest in scale of the commemorative performance events took place on 28 April 2013 on those same Fellman's Fields in Lahti where the escaping convoy of 22.000 Reds was halted and imprisoned ninety five years earlier. It was designed by the visual artist Kaisa Salmi, whose performance, Fellman's Field, was realised with the support of several leftist organisations and gathered some 10 000 people, ${ }^{72}$ who choreographically re-enacted the suffering of all the prisoners, and aimed at an emotional engagement and, as they asserted, reconciliation. Salmi tried to deny her political implications by talking about a "national tragedy" and suffering on a general level. The artist even tried to deny a connection to the history seminar organised by labour organizations just the same weekend in Lahti. In the social media she was criticized as being either naïve or a hypocrite: Fellman's Field was a clearly political act engaging the Red victim narrative, without a broader understanding. For the purposes of this article the event can be understood as an enforcement of identity at a time when the voting for the two historical left parties had gradually fallen to no more than $28 \% .{ }^{73}$

\section{THE CENTENNIAL OF THE CIVIL WAR IN HELSINKI}

The Centennial in 2018 was notable especially in Helsinki and Tampere. - Both cities could provide interesting site-specific performances.

Two such performances emerged in Helsinki. Theatre Avoimet Ovet [Open Doors] started with a reality-based story of a maid serving in a bourgeois family in Helsinki. She joins the Reds and will be executed at the end. The production was acclaimed by critics for its important discussion around class and gender. ${ }^{74}$ Helsinki City Museum invited a group of artists to create an installation and a production (opened on 1 February 2018), which used authentic quotes and texts from 1918, taking the Red and the White parts of the city into consideration, using old and new photographs and material objects. The audience followed the actors around in the museum building, an old aristocratic villa located on the White side of the city but with windows and balconies overlooking the water on the workers' side. The performance was very appreciatively received. ${ }^{75}$

Interestingly, a new variation of the theme "actors in Civil War" was created in the autumn of 2017, about an actor, one of the Red leaders, who during his imprisonment in Suomenlinna in order to avoid execution, makes a deal to rehearse a hilarious theatre performance for Finnish and German officers. This black comedy was also successfully filmed (2018). ${ }^{76}$

72 Helsingin Sanomat 29.4.2013.

73 Korsberg \& al. 2019 accordingly discuss the same event as an emotional engagement, which it clearly was. But if it was done in order to "help to understand the complexity of national trauma" it did not succeed: it gave the possibility for engagement with mass empathy only for the Red victim narrative. This is visible in the facebook commentaries quoted by the authors, who for their part seem to stand behind the artist. But her statements were politically either naïve or hypocritical. Kinnunen 2014, 435-436 also naïvely follows the artist and reads the event as unpolitical or unbiased.

74 https://www.avoimetovet.fi/menneet/erottaja-1917-18/ and Maria Säkö, Helsingin Sanomat 14.9.2017; Otto Ekman, Hufvudstadsbladet 15.9.2017. (accessed in 15.1.2020).

75 http://hakasalmivilla.fi/exhibition/vihan-kevat-helsinki-1918/; See Maria Säkö Helsingin Sanomat 2.2.2018; Sirpa Puhakka Kansan Uutiset 5.2.2018. (accessed 15.1.2020).

76 Parikka's memoires (1938) were unique as he was the only Red field officer who survived and could later write a precise description of the events on the Eastern front and in Vyborg. Mikko Reitala wrote the comedy Suomen hauskin mies [The most hilarious man of Finland] first seen in Helsinki City Theatre in 2017. 
KOM-teatteri's production of The Roses of Blood became a major theatre event in Helsinki. Lauri Maijala had adapted the novel by Anneli Kanto and used students of the Theatre Academy in the girls' roles. Kanto had published her novel Veriruusut, [The Roses of Blood] in 2008. The protagonists were now the factory girls from Valkeakoski and Tampere, who - not surprisingly - have been also sexually abused by the foreman in the factory. After joining the Red guard, they mostly died in action, in field shootings and quick executions and of those that did not, some were raped in imprisonment while awaiting trial. The focus is on their hopes, but also on the issue of equality: unlike all other jobs, the Red guards paid female and male soldiers the same rate.

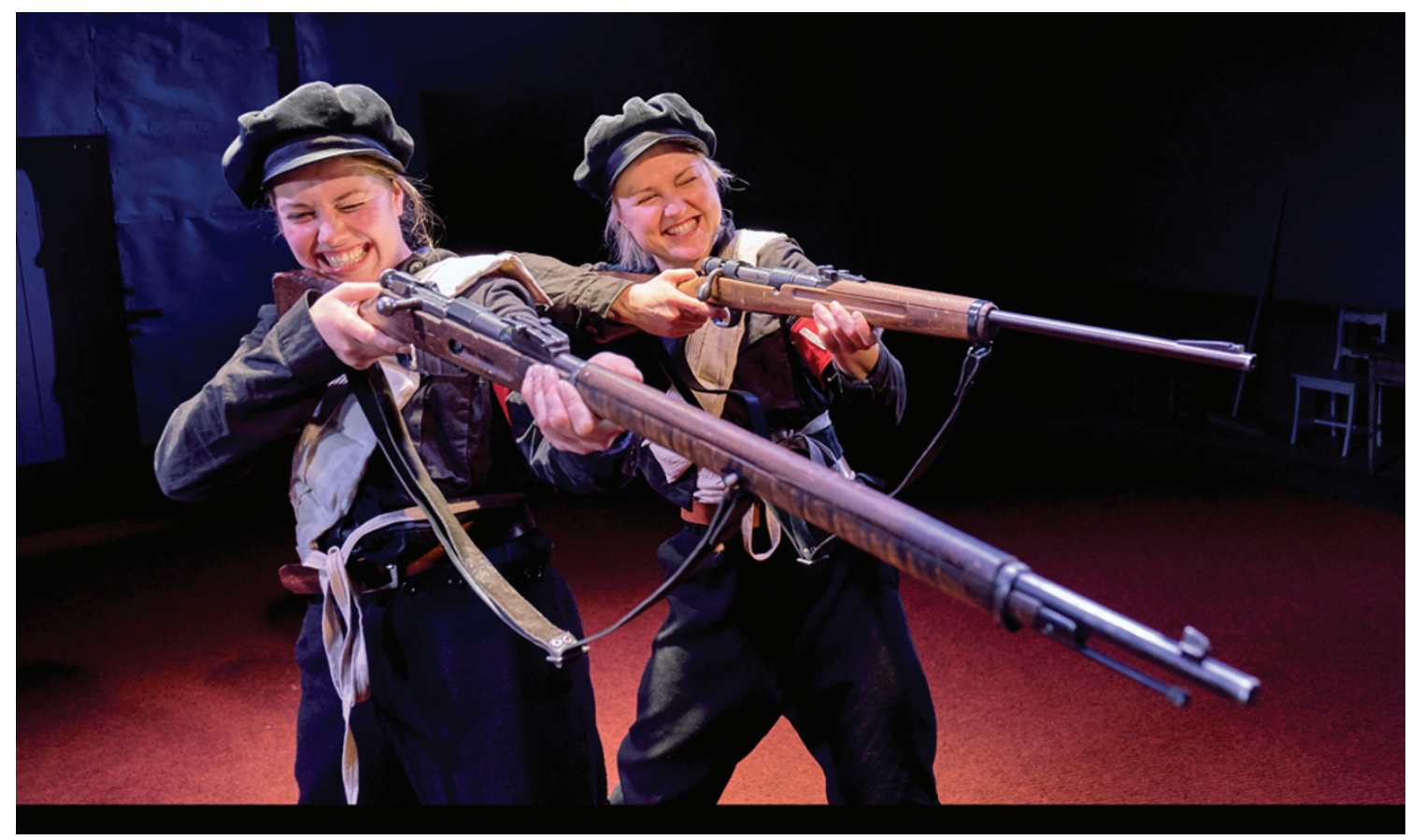

FIGURE 1. Anneli Kanto \& Lauri Maijala: The Roses of Blood in KOM-teatteri 2018. Director: Lauri Maijala. Maija and Sigrid have got their first rifles, Oona Airola and Helmi-Leena Nummela. Photo: Marko Mäkinen.

Despite the topic, the performance itself was designed to be very intimate. A front of house audience of 300 spectators, some ten actors, with doublings and triplings in the episodes. The girls were shown in the process of empowering themselves. Firstly: in joining the Red guard; secondly by dressing themselves in trousers, thirdly by obtaining a rifle and, fourthly by contributing equally to the revolution. The traditional songs of the Reds were sung to one guitar or mandolin in unison, which was also a nostalgic feature for KOM's elderly audiences, who had been there in the 1970s.

It is interesting to note how instructions were given for the revolution to begin: someone simply shouts the news that "now the Red lantern has been lit in the Helsinki Workers' house tower". The girls react with enthusiasm to this message from the capital. Similar to Linna, Kanto's narrative gives them place only as loyal nipples of a greater machinery. The war landscape is drawn by three to four glimpses of complete chaos around the girls in the field. They were shot as prisoners near the Fellman's Fields in Lahti. They quickly changed their trousers to robes, but that did not help. The White image of these "red female beasts" who 
were furious in the battle was strong and it would be best for the victors to get rid of them without delay. The fear that these women would spoil the pure race of the new Republic was in the air - all mixed up with elements of ethnic cleansing. ${ }^{77}$ The Roses of Blood in KOM was a very non-spectacle event, simple, empathic, political; where no ambiguities were disturbing; but also, the enemy was absent; the White soldiers were never seen, only the foreman is a negative character performed by an adult actress in Brechtian style.

\section{THE CENTENNIAL OF CIVIL WAR IN TAMPERE}

In Tampere, 'the industrial and Red capital of Finland', three major productions were created, which unlike Helsinki, were large scale performances. The Red narrative got its major exposition in the TTT, the Tampere Workers' Theatre, which created the performance Tytöt 1918, [Girls 1918] based on the same novel Blood Roses by Anneli Kanto. ${ }^{78}$ This variant was a spectacle with great pathos on a huge stage and good resources: a cast of thirty nine including singing actors and dancers, an orchestra of seven, plus an extra youth choir of forty six in the finale. With its video projections and technological equipment this Tampere centred version of Kanto's Roses of Blood became a lengthy spectacle, with twenty two musical numbers. Here was the "official Red version" as it might be called. Girls 1918 in TTT was a perfect "red musical" with strong ingredients for any identityconstruction in the present-day Tampere.

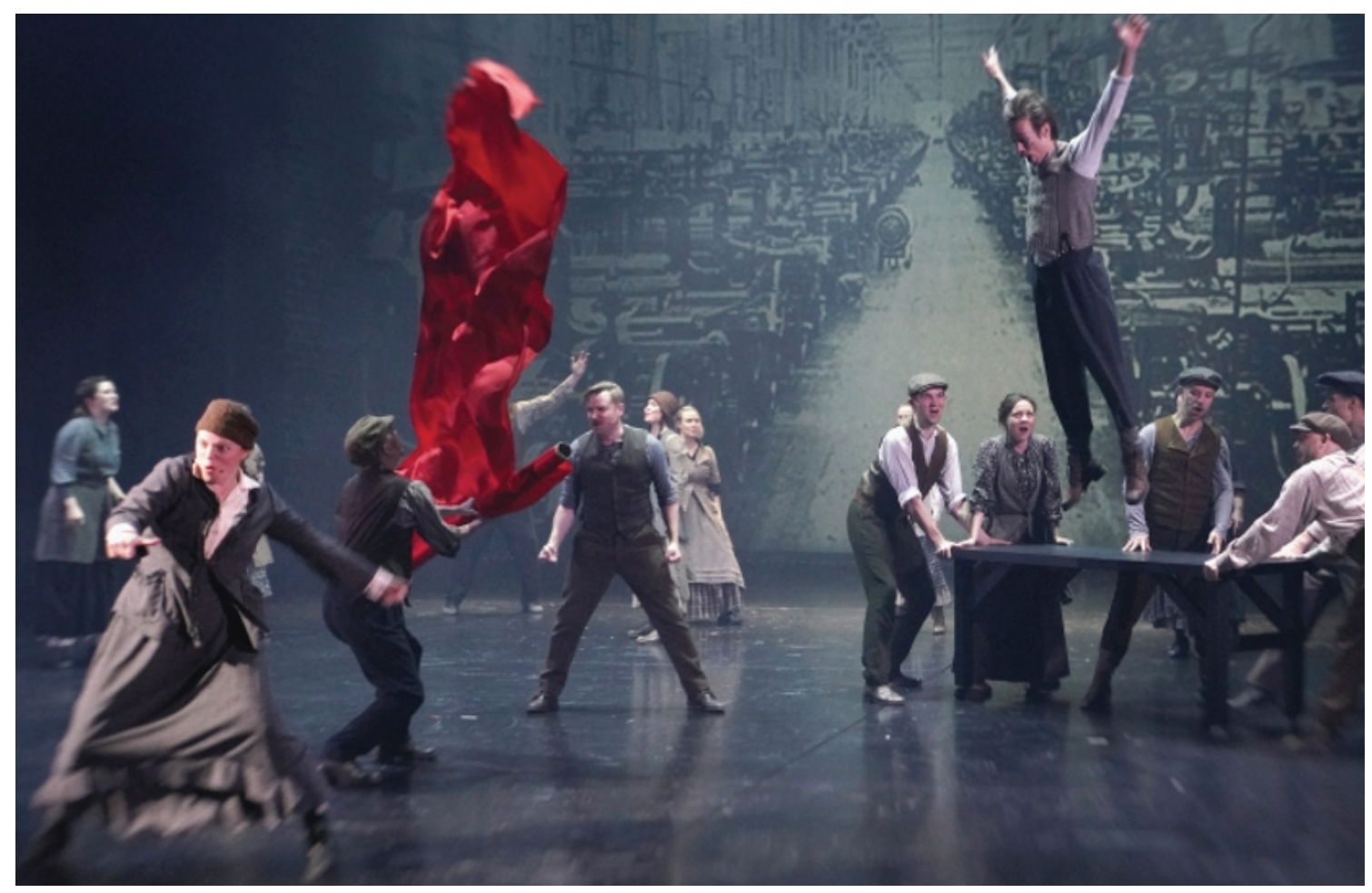

FIGURE 2. Director Sirkku Peltola's adaptation Girls 1918 was also based on Anneli Kanto's novel The Roses of Blood. Tampere Workers' Theatre 2018. Scenography: Hannu Lindholm. Photo: Kari Sunnari.

77 The author Anneli Kanto was well read in the new and detailed research on these topics.

78 Kanto's novel's second stage adaptation was by a talented author and director, Sirkku Peltola. 
Most of the Finns today have family roots in both camps. For Anneli Kanto it was also a surprise that one of her grandfathers from the Ostrobothnia, had actually joined the White peasant troops in the Civil War. Kanto felt forced to learn and write the story of him and other ordinary men from the Ostrobothnia who were drafted into the new White army. The title of the novel Lahtarit [The Slaughters] (2017) repeats the aggressive sobriquet used by the Reds for the Whites. Director Sari Lillienstierna made the adaptation for her small theatre group Sarin sakki [Sari's gang] in 2018. It was welcomed as one new version of the events, of how wearying the memories and the sorrow could also be on the White side. ${ }^{79}$

The second major production in Tampere was an opera by the composer Olli Kortekangas as the librettist and directed by Tuomas Parkkinen. It carried the Biblical title Veljeni vartija, [My Brother's Keeper]. This is the answer to the first fratricide, when God asks Kain: "where is thy brother Abel?". - Kain says: "I don't know. Am I my brother's keeper?" Parkkinen and Kortekangas are clear in their answer: "yes, you are!" You and all of us are responsible for no longer leading our lives into fratricide.

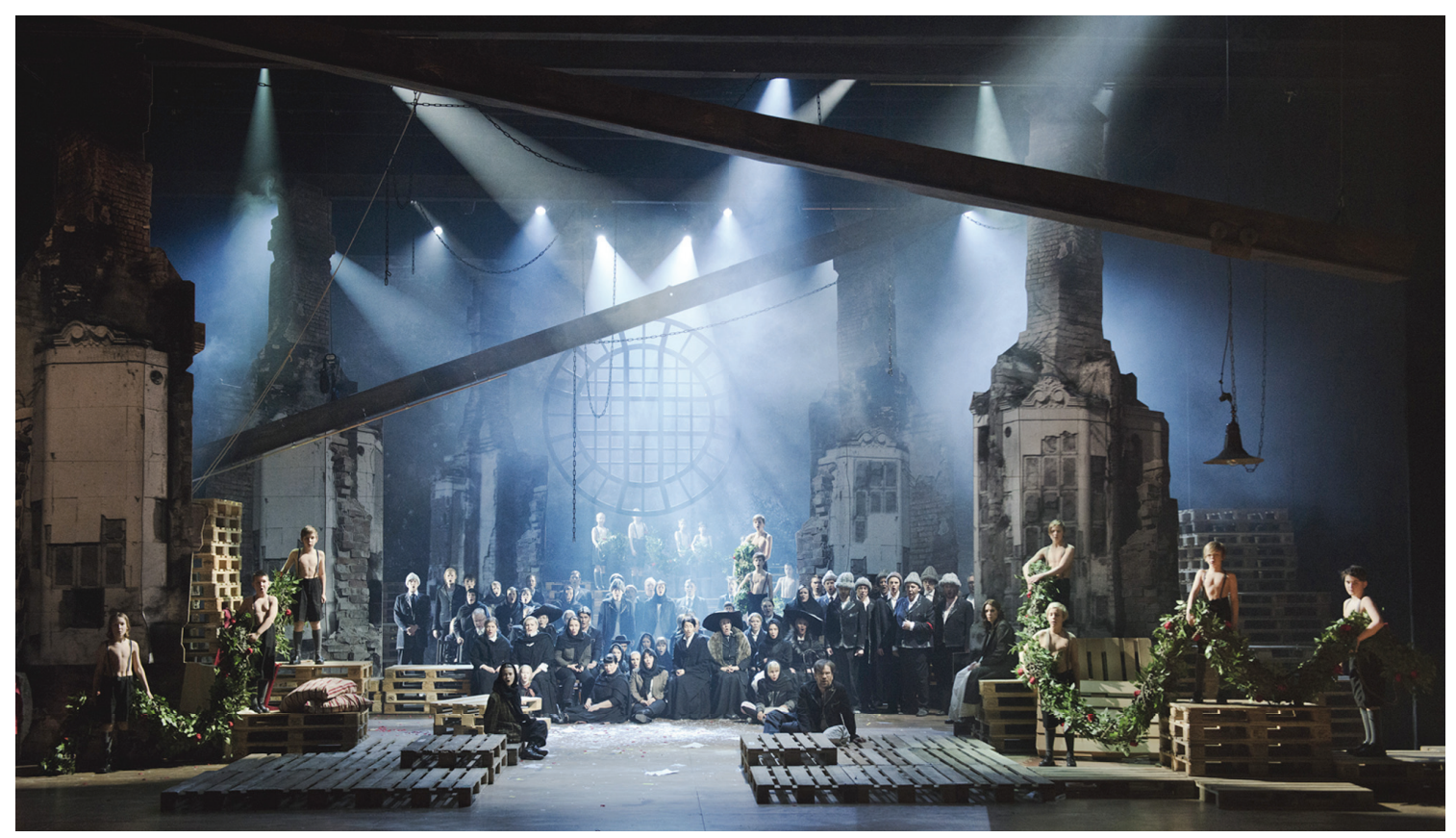

FIGURE 3. Olli Kortekangas composed his opera My Brother's Keeper on the libretto by Tuomas Parkkinen, who also directed the opera in 2018 for the Tampere Opera. The scenography designed for the Tampere Concert Hall by Kati Lukka combines here the burnt city and the Cathedral. The boys carrying the rose wreaths refer to the famous symbolist paintings by Hugo Simberg. Lights designed by Ville Syrjä. Photo: Petri Nuutinen.

The music of the opera is impressive, but the family intrigue of a brother and sister on opposite sides somewhat unconvincing and artificial with its use of extra allegorical and symbolic characters. The work was performed in the Tampere-talo Concert Hall, yet utilised full stage techniques. The culmination was based on the

79 See K. Fleming in Tamperelainen 2.3.2018. 
same incident that had inspired another performance ten years earlier: the seeking of refuge by a group of people who came to occupy the new St. John's Church in Tampere, the present Tampere Cathedral. ${ }^{80}$ The subtle a cappella chorus of the refugees asks:

O you, who once decided: we take the path of war

I don't wish you dead, but I wish you will live a long life

and meet the deeds of your hands.

You see no more a Red man, you find no White

You only see the black, the black

In distance, where eye cannot carry, where eye cannot carry. ${ }^{81}$

The third major production in Tampere during the Centennial was a uniquely interesting site-specific performance called 1918 Teatteri Taistelussa; [1918 Theatre in the Battle]. During the Civil War the house of Tampereen Teatteri, (TT, Theatre of Tampere) had been brand new, built in 1913 as a result of the generosity of the city merchants, to provide the city an orderly theatre space, including an orchestra pit, a balcony and a foyer. At the other end of the house, behind the stage area, is a restaurant looking east over the main arterial of the city, the rapids of Tammerkoski, which gives the city its Swedish name Tammerfors. The western façade opens to the Central Square, opposite to the City Hall.

The performance, scripted by the historian Tuomas Hoppu and Director AnnaElina Lyytikäinen, opens on the night of 14 January 1918, on the centennial of a national author, Zachris Topelius. His historical drama Regina von Emmeritz was played on the stage. ${ }^{82}$ As the war broke out ten days later, the Director of the theatre fled towards the north in order to join the White troupes, while the actors should remain in town. The Red guards invaded the theatre as it had been assigned to them as their billet. This troop was played by schoolboys sixteen to seventeen years of age heralding the start of the revolution. Beyond these eleven boys, there was a cast of twenty actors who all played between one and five characters and a girl who was nine to ten years old. Recorded music and projections were used. Real or documentary characters as well as fictional characters were written in, such as people of the theatre restaurant, which had been appointed the centre for provision of the Red guards.

There was also some love intrigue, and the character of a Russian lady who took care of the medical station. One man in the cast was fluent in Russian and he could play a Russian officer who was engaged to help the Reds in military operations. But a shouting Russian officer could not do much for drunken Finnish soldiers, not the least get them to the front line. Even a \#metoo -theme was evoked, when the daughter of the restaurant cook was about to be touched by the drunken Red soldiers.

80 The Cathedral is the most impressive total work of art with remarkable symbolistic frescoes, one of which ('The Rose Wreath Bearing Boys' by $\mathrm{H}$. Simberg) was subtly animated on the stage. 81 Transl. by Pentti Paavolainen; original by Tuomas Parkkinen.

82 In January 1918 the Workers' Theatre also played Finnish classics and A Midsummer Night's Dream by Shakespeare. 
The performance also depicted the dilemmas of those commanders leading the defence of Tampere, ranging from single soldiers and officers to the commanders of all the Red warfare. At least two of these commanders had their only training in workers' theatres: the amateur actors could adapt themselves to any situation convincingly enough. The big problem, which evolved from the locality of the TT theatre house and its restaurant, was the excessive use of alcohol by the Reds. The unorganized and undisciplined spirit of "freedom" (svoboda) made the task of any leader very difficult. "We have lost this war already", was the clear understanding of the men over the glass.

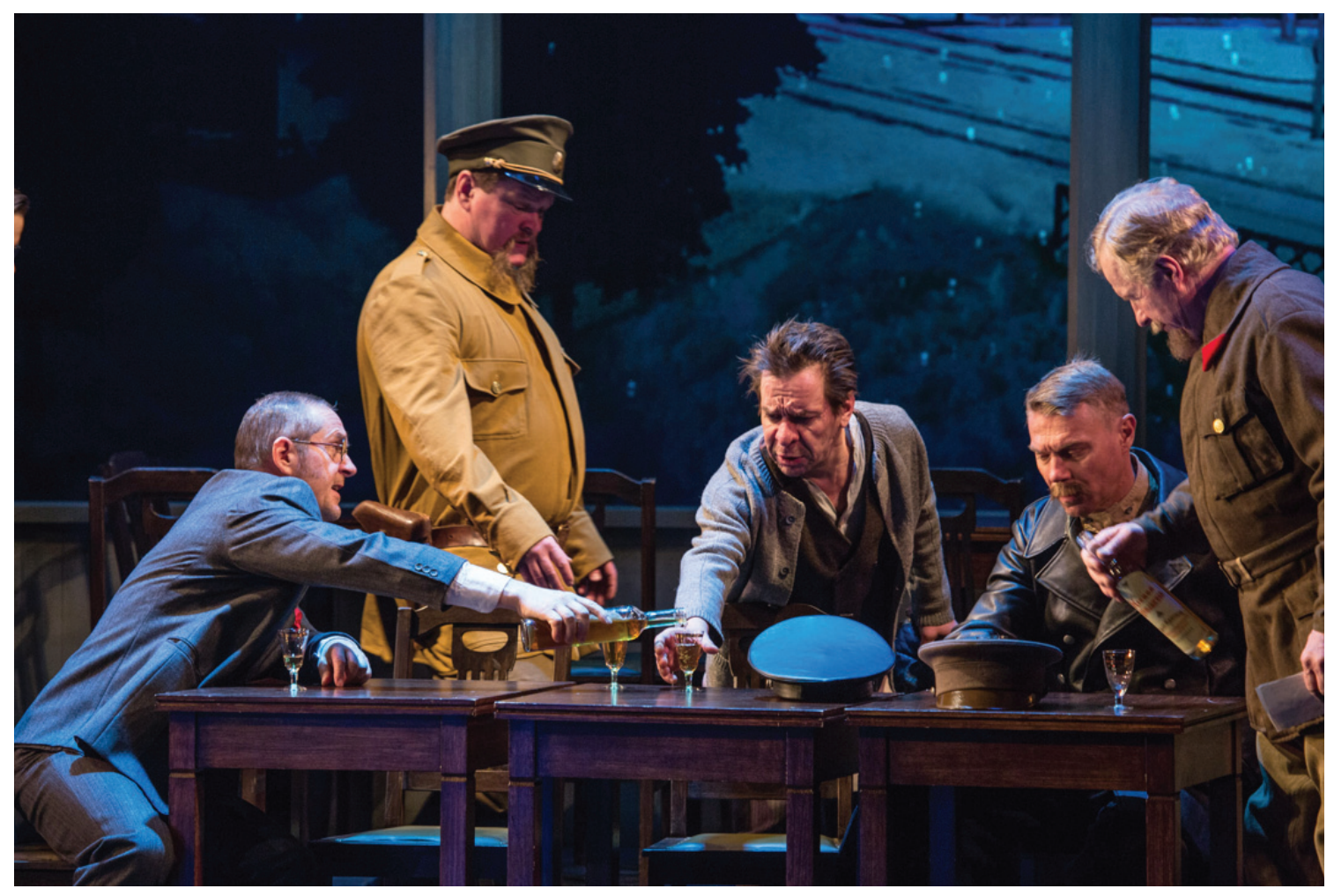

FIGURE 4. 1918 Theatre in the Battle was the site-specific performance in the Theatre of Tampere in 2018. Its factual base was by the historian Tuomas Hoppu, the dramaturgy and direction by Anna-Elina Lyytikäinen. The local red leadership negotiates. From left to right: Jukka Leisti, Ville Haapasalo, Risto Korhonen, Esa Latva-Äijö and Markku Thure. Photo: Heikki Järvinen.

With a couple of exceptions, the events in the performance took place between the walls of the actual theatre house and its immediate surrounding. Yet live camera techniques are used to follow the last Red machine gun trying to prevent the Whites from coming along the bridge over the rapids from the east. The live camera followed the checking of the corridors, the shooting and cleaning the houses of all the Reds. A group of prisoners was taken from volunteers in the audience. As the Reds then fled over the square to the City Hall, the White machine guns were posted in the windows of the theatre foyer.

An interesting fictive scene developed between the Red cook of the restaurant and a White sergeant, who met in the audience space and on stage. The dialogue goes like this: 


\section{R: Got a cigarette?}

W: Here you are. (They smoke, pause) Why did you really start this revolution?

$R$ : We wanted the 8-hour working decree.

W: But that was ordained already in November.

$R$ : The patrons' power has been oppressing us so heavily ...

for so long ... (pause).

well, I have my daughter ... for her ....83

The last Reds of Tampere capitulated within a day coming out of the City Hall on the Central Square and several thousand men were kept imprisoned on the square for three days while camps were prepared. The performance ended when the theatre director returned: "we won't play anymore this spring; this must be all repaired, so that a new company can start in the autumn." Leaving the theatre house, the audience sees damages and corpses in the entrance hall.

Teatteri sodassa 1918 evaded the overall ideological preferences, except those expressed by its characters. It concentrated on the actual events around the new theatre-house, and became a profound site-specific theatre performance. In so doing it presented several fractures in the Red victim narrative without accusing the Whites nor forgetting the human responsibilities of each person.

\section{FINAL ARGUMENTS AND CONCLUSIONS}

The Red trauma of the Civil War was carried for the first forty years by the workers' societies and Social-Democratic party organisations. The trauma also produced some revenge spirited class-war literature, but it was never allowed visibility in the bourgeois public sphere of the republic. A silence prevailed over the experiences and memories of the Red participants until 1959, when Linna's novel was published.

Some of the White traumas could be discussed, like the unexpected fracture in the emerging of the independent nation-state and the disappointment at the hatred shown by the lower classes. But their silenced trauma was responsible for the exaggerated violence, the suffocated guilt of the executioners. Probably relief from that came in the gradual beginning of a politics of social reform from the late 1930s.

The first wave of theatre performances of the 1960s dealing with the Civil War allowed for a direct look at the events and assisted in creating awareness and acceptance of the story of the Reds. In those years some of the participants, victims and eyewitnesses from both sides were still alive and they retained their versions of the events. The original carriers of trauma were interviewed and recorded for TV and made an entrance into public discourse.

This process of the admission of the facts on both sides, created the basis for modern research on the topic. But now in addition, the carriers of the traumas could relate their experiences of what was recorded in the facts and were expected to abandon the exaggerated legends of horror of the enemy, which had been kept alive for decades.

83 Quoted and translated according to the performance notes by the author of this article. 
Simultaneously however, numerous members of the baby boomer generation (those born between 1945-1951) were approaching adulthood. Particularly those who were the first university students in their family line had questions about their identity as future academically educated Finns. For them the memory of the Civil War and especially the victim-narrative of the Reds became a corner-stone in their identity, especially if their grandparents had been on the Red side. Not unlike in Western Europe, the 1968-1969 radicalisation of the artists and theatre people invited all the histories of class struggle to be staged in most countries. ${ }^{84}$ According to Jeffrey Alexander, the young made the claim that the Red narrative should be heard, and so they logically became the forward carrying trauma-constructors despite how far left they stood politically. Thus, the Red narrative of the Civil War became a somewhat new generational narrative for Finland.

In post 1969 Europe, the Cold War antagonism defined the domestic politics in many countries. As long as the Soviet Union was the neighbour of Finland, any strong leftist opinions always ultimately questioned the loyalty of the speaker: the Red and White controversy had the ultimate implication on the existence of the independent democratic state of Finland. This explains the tendency to some fanaticism in the issue of the Civil War. It is obvious how well the North Star II was suited for the trauma-construction in 1960s Finland and how the elements needed for such a process were at hand in the society. It also replaced the older narrative, imposed by the Whites on the Reds; namely that of the "innocent people cynically mislead by radical, incompetent and cowardly agitators."

In the Red narrative of the 1960s the responsibility was directly attributed to the Whites, as the Bolshevik interference was regarded as not politically correct to mention because at that time, the Soviet Union was assigned the role of 'benefactor of Finland'. In the politically antagonistic context of the 1960s it was all about class-struggle and the sins were attributed to the White Finland, as most of the people who held positions in the society could be said to be heirs of the Whites. ${ }^{85}$

Today in 2019 the conclusion is mostly unquestioned: the Red victory in 1918 would have resulted in the annexation of Finland by Soviet Union. ${ }^{86}$ But in Finland between 1944-1991 the Soviet Union informed most discussions in the public sphere. Therefore, Lenin should be presented as "nobly signing the concession for the independence" and it was forgotten that two weeks later he sent a train full of weapons to the Reds for the purpose of overthrowing the same government.

Unquestioned, the Red narrative was repeated for thirty years in theatres until the 1990s when fractures in the fatalistic victim narrative started to appear. These were adopted to some performances and paved the way for a more balanced view

84 The French Revolutions have inspired much drama. See Rokem 2000. Such as Büchner, Rolland, Weiss, Brecht, not forgetting the French musical Les Misérables, which later, adapted for London, gained huge popularity.

85 Väinö Linna's overall aim in his three-part novel was, however, to describe the way to a national reconciliation and to heal the wounds by discussing the essential conflicts of the closest past.

86 The recent scholarship leaves no doubts on this issue. See Lackman's 2017 biography of the Red dictator Kullervo Manner. 
on the Civil War. ${ }^{87}$ Still the heroic and victimized Red narrative remained dominant. These variants could both be seen in the three major 1918 commemorative theatre productions around the Centennial. The understanding of the White narrative was observed in public discourse elsewhere in the society, but it has not found its way onto the stages this far, although some elements were found in the Centennial productions.

In dealing with the Civil War in theatre, a new era should emerge where both sides can benefit from a new and a dramatically interesting treatment. As a young director put it:

"In theatre we have seen masses of descriptions where the Whites are upper class villains. With that black and Whiteness, [l am] 'very much tired of '." 88

\section{AUTHOR}

Pentti Paavolainen is a Docent at the University of Helsinki. His PhD dissertation (1992) was a sociological analysis of the theatre repertories of the 1960s in Finland. In 19932007 he held the Chair of Theatre Research in the Theatre Academy, today the University of Arts, Helsinki, where he developed the doctoral programs for research. He served as the chair for the Nordic Society of Theatre Research (NTF/NTS 1995-1999), and a visiting professor in Malmö Theatre College (Sweden) 2003-07. His works include a monograph (1987) on the early career of the director Jouko Turkka and a major biography of Kaarlo Bergbom $(2014,2016,2018)$, the portal figure of 19th theatre and opera in Finland.

87 One of the scriptwriters for TT was Tuomas Hoppu, an academic scholar who has published on the subject.

88 Milja Sarkola's interview in Suomen Kuvalehti 10/2019 (8.3.2019): "Teatterissa taas on nähty joukoittain kuvauksia, joissa valkoiset ovat yläluokkaisia pahiksia. Siihen mustavalkoisuuteen Sarkola sanoo olevansa 'tosi kyllästynyt'. " 


\section{REFERENCES 89}

Alexander, Jeffrey C. et al. 2004. Cultural Trauma and Collective Identity. Berkley, Los Angeles, London: University of California Press.

Alexander, Jeffrey C. 2012. Trauma: A Social Theory. Cambridge. Malden: Polity Press.

Anhava, Jaakko. 1996. "Mitä 'me' olemme tehneet." Helsingin Sanomat 6.9.1996.

Kalemaa, Kalevi. 2012. Veljekset kuin ilvekset: Kertomus Lauri ja Rafael Haarlasta. Tampere: Mediapinta.

Kinnunen, Tiina. 2014. "The Post-Cold War Memory Culture of the Civil War: Old-New Patterns and New Approaches." Tuomas Tepora, \& Aapo Roselius (eds.) The Finnish Civil War 1918: History, Memory, Legacy, History of Warfare, 101. Leiden: Brill. 401-440.

Korsberg, Hanna, Aho, Laura-Elina, Chassany, Iris, Valtanen, Sofia. 2019. "Remembering the Finnish Civil War: Embodied Empathy and Fellman Field." Theatre Research International 44:1, $6-22$.

Koski, Pirkko. 2000. Kaikessa mukana: Hella Wuolijokija hänen näytelmänsä. [Active in everything: Hella Wuolijoki and her Plays.] Helsinki: Otava

Koskimies, Rafael. 1972. Suomen Kansallisteatteri 2: 1917-1950. [The Finnish National Theatre: Part 2. 1817-1950.] Helsinki: Otava

Lackman, Matti. 2017. Kullervo Manner: kumouksellisen muotokuva. [Kullervo Manner: Portrait of a Revolutionary.] Somero: Amanita.

Lavery, Jason. 2006. The History of Finland. Westport, CT: Greenwood Press.

Lehtonen, Soila. 2018. Draamaa Suomenlinnassa. Hyvän omantunnon kesäteatteria. [19702017]. [Ryhmäteatteri]. [Drama in Suomenlinna. Summer theatre in the Godt Samvete Bastion 1970-2017.] [The Group Theatre.] Helsinki: BoD - Books on Demand.

Lilja, Jenny. 1979. Dramaatikon visiot: tutkimus ekspressionistisista teemoista ja motiiveista Lauri Haarlan näytelmissä. [The Visions of a Dramatist: Study on the Expressionist Themes and Motifs in the Plays by Lauri Haarla.] (diss.) Jyväskylä Studies in the Arts. 12. Jyväskylä: Jyväskylän yliopisto.

Långbacka, Ralf 2011. Taiteellista teatteria etsimässä. [In Search for an Artistic Theatre], original På jakt efter en konstnärlig teater. Transl. Hannimari Heino. Helsinki: Siltala.

McConachie, Bruce. 1989. "Reading Context into Performance: Theatrical Formations and Social History". Journal of Dramatic Theory and Criticism. Spring 1989.

89 Newspaper and Magazine articles, web sources are given in footnotes.

Plays mentioned in the text are not listed here, but they are findable in catalogues:

https://uniarts.finna.fi/ Catalogue Arsca provides the Library of the Theatre Academy and the Library of the Sibelius Academy at the University of the Arts, Helsinki.

http://www.naytelmat.fi/ Catalogue of the Library of the Finnish Playwrights' Union.

https://www.dramacorner.fi/fi Catalogue of the Library of the Nordic Drama Corner, an agent for domestic and translated plays.

The data of the theatrical productions in Finland is findable in: http://ilona.tinfo.fi/. 
Ollikainen, Anneli \& Tanskanen, Kirsi (eds). 2013. KOM-kirja. [KOM-book] Helsinki: Like.

Paavolainen, Jaakko 1967. Poliittiset väkivaltaisuudet Suomessa 1918: 2 Valkoinen terrori. [The Political Violence in Finland 1918: 2. The White Terror.] Helsinki: Tammi.

Paavolainen, Pentti 1992. Teatteri ja suuri muutto. Ohjelmistot sosiaalisen murroksen osana 1959-1971 (väitöskirja). $270 \mathrm{~s}+54 \mathrm{~s}$ liitteet + taulukot. Suomen Teatterijärjestöjen Keskusliiton 50-vuotisjuhlakirja. Helsinki: Kustannus Oy Teatteri. [Theatre and the Great Migration. The Repertories of 1959-1971 as part of the social change. (PhD dissertation, University of Helsinki) $270 p+54 p+t a b l e s$. The 50 year anniversary publication of the Finnish Union of Theatre Organisations. Helsinki: Publisher Teatteri.]

Paavolainen, Pentti. 2005. "Ernst Tollerin Hinkemann - avainteos 1920-luvulla." Esitys katsoo meitä. Näyttämö ja tutkimus 1. Teatterintutkimuksen seura ry:n vuosikirja. Toim. Pia Houni, Pentti Paavolainen, Heta Reitala, Hanna Suutela. Verkkojulkaisu www.teak.fi/teats ja Yliopistopaino. 2005. ["Hinkemann by Ernst Toller - Key Work of the 1920's Finland", in Performance looks at us, Stage and Research 1. The Year Book of the Finnish Association for Theatre Research TeaTS. Eds. Pia Houni, Pentti Paavolainen, Heta Reitala, Hanna Suutela. Net publication in www.teak.fi/ teats, Helsinki UP. 2005]

Paavolainen, Pentti. 2015. "Välskärin kertomukset" ja teatteri. Teoksessa Ennen kuulemattomat Välskärin kertomukset. ["The Surgeon's Stories and Theatre". Leena Kirstinä (ed.) The unheard Surgeon's Stories.] Toim. Leena Kirstinä. Topelius-seura. Helsinki. 2015. 130-157.

Parikka, Jalmari. 1938. "Viimeinen taisto": Punaisen rintamapäällikön muistelmia v:Ita 1918. Alahuomautukset laatinut U.V. Rauanheimo. WSOY: Porvoo - Helsinki. ["The last battle": Memoires of 1918 by a red field officer. Footnotes by U. V. Rauanheimo.]

Rajala, Panu. 2018. Suomussalmen sulttaani: Ilmari Kiannon elämä. [The Sultan of Suomussalmi: The life of IImari Kianto.] Helsinki: SKS

Rokem, Freddie 2000. Performing History: Theatrical Representations of the Past in Contemporary Theatre. Studies in Theatre, History \& Culture. Ed. Thomas Postlewait. U of lowa Press: lowa City.

Roselius, Aapo. 2014a. "Holy War: Finnish Irredentist Campaigns in the Aftermath of the Civil War." Tuomas Tepora, \& Aapo Roselius (eds.) The Finnish Civil War 1918: History, Memory, Legacy. History of Warfare, 101. Leiden: Brill. 119-155.

Roselius, Aapo. 2014b. "The War of Liberation, the Civil Guards, and the Veterans' Union: Public Memory of the Interwar Period." Tuomas Tepora, \& Aapo Roselius (eds.) The Finnish Civil War 1918: History, Memory, Legacy. History of Warfare, 101. Leiden: Brill. 297-330.

Saarela, Tauno. 2014. "To Commemorate or not: The Finnish Labour Movement and the Memory of the Civil War in the interwar Period" in Tuomas Tepora, \& Aapo

Roselius (eds.) The Finnish Civil War 1918: History, Memory, Legacy, History of Warfare, 101. Leiden: Brill. 331-363.

Seppälä Mikko-Olavi 2010. Suomalaisen työväenteatterin varhaisvaiheet. [The Early Phases of the Finnish Workers' Theatres.] (diss.) Suomalaisen Kirjallisuuden Seuran Toimituksia 1272. Helsinki: SKS.

Silvennoinen Oula, Roselius Aapo, Tikka Marko, 2016. Suomalaiset fasistit: mustan sarastuksen airuet. [The Finnish Fascists: Herolds of a Black Twilight.] Helsinki: WSOY.

Spalek, John M. 1968. Ernst Toller and his Critics: A bibliography. Charlottesville. 
Sztompka, Piotr. 2000. "Cultural Trauma. The Other Face of Social Change." European Journal of Social Theory. 3:4, 449-466.

Tarkka, Pekka. 2003. Pentti Saarikoski II (vuodet 1964-1983). [Pentti Saarikoski II: the years 1964-1983] Helsinki: Otava.

Tepora, Tuomas. 2014b. "Changing Perceptions of 1918: World War II and Post-War Rise of the Left." Tuomas Tepora, \& Aapo Roselius (eds.) The Finnish Civil War 1918: History, Memory, Legacy. History of Warfare, 101. Leiden: Brill. 364-400.

Tepora, Tuomas \& Roselius, Aapo. (eds.) 2014. The Finnish Civil War 1918: History, Memory, Legacy. History of Warfare, 101. Leiden: Brill.

Tepora, Tuomas and Roselius, Aapo. 2014a. "Introduction: The Finnish Civil War, Revolution and Scolarship." Tuomas Tepora, \& Aapo Roselius (eds.) The Finnish Civil War 1918: History, Memory, Legacy. History of Warfare, 101. Leiden: Brill. 1-20.

Tikka, Marko. 2014. "Warfare and Terror in 1918." Tuomas Tepora, \& Aapo Roselius (eds.) The Finnish Civil War 1918: History, Memory, Legacy, History of Warfare, 101. Leiden: Brill. 90-118.

Ylikangas, Heikki. 1993. Tie Tampereelle 1918: dokumentoitu kuvaus Tampereen antautumiseen johtaneista sotatapahtumista Suomen sisällissodassa. [The Way of Tampere 1918: A Documented Description of the War Events Leading to the Surrender of Tampere in the Finnish Civil War.] Helsinki - Porvoo: WSOY.

\section{DOCUMENTATION OF PERFORMANCES WITH THE FINNISH CIVIL WAR ON THE STAGES}

The following list contains domestic dramas (in Finnish and in Swedish) in which the main subject or theme can be recognised as dealing with the 1918 Civil War. The premiering theatre is given. The plays and adaptations of novels were often performed in other professional and amateur venues around the country. The given years are limited to the professional revivals. The asterisks refer to information in Seppälä 2010, *) pages 302-303 and **) pages 305-308.

\section{7}

Elviira Willman-Eloranta: Vallankumouksen vyöryssä [In the Flow of Revolution] *)

Elviira Willman-Eloranta: Veriuhrit [The Blood Offers] ${ }^{*}$ )

1919

Runar Schildt: Hemkomsten [Homecoming] novel, later stage adaptation

1921

Sam Sihvo: Jääkärin morsian [The Jaeger's Bride], SKT [Finnish National Theatre], 1921, 1922, 1923, 1924, 1925, 1926, 1927, 1928, 1929, 1930, 1931, 1932, 1933, 1934, 1935, 1936, 1937, 1938, 1939, 1940, 1941, 1942, 1943, 1944, 1948, 1954, 1955, 1956, 1957, 1961, 1964, 1965, 1967, 1968, 1969, 1970, 1971, 1972, 1981, 1982, 1991, 1995, 1997, 2000, 2003.

Verneri Jokiruoho: Veljesvihaa [Fraternal Hate] ${ }^{* *}$ )

Unto Kekäläinen: Valkoinen kosto [White Revenge] ${ }^{* *}$ )

1922

Verneri Jokiruoho Voitetut sankarit [The Defeated Heroes] ${ }^{* *}$ ) Kaarlo Valli: Sovittamattomat [The Irreconcilables] ${ }^{* *}$ ) 
1923

IImari Kianto: Hallan jääkärit [The Jaegers in Halla], Kajaani Drama Society

Runar Schildt: Den stora rollen [The Great Role] SvT [Swedish Th.] 1923, 1928, 1938, 1966, 2001; in Finnish Suuri rooli 1927, 1928, 1929, 1939, 1996.

1928

Jarl Hemmer: Gehenna och ljusstrålen. [Gehenna and the beams of light] playscript not performed 1931

Jarl Hemmer: En man och hans samvete [A Man and his Conscience], novel

1932

Lauri Haarla: Kaksiteräinen miekka [Double-edged sword] Vyborg City Th., 2006.

1933

Hella Wuolijoki: Laki ja järjestys [Law and order] Koitto Stage/People's Theatre.

Risto Kuusi (pseudonym for Kersti Bergroth \& Leon Grandell): Jääkärit [The Jaegers] SKT [Fi.Nat. Th.]

1960

Väinö Linna: Täällä Pohjantähden alla II. (Here Under the North Star, part II.) Novel.

1961

Väinö Linna \& Eugen Terttula: Täällä Pohjantähden alla II [Here under the North Star II]. TTT [Tampere Workers' Theatre]. Also in other adaptations: 1962, 1963, 1964, 1965, 1967, 1968, 1977, 1978, 1979, 1989, 1992, 2002, 2006, 2007, 2008, 2011, 2017.

1972

Lauri Sipari: Suomen kuningas [The King of Finland].

1975

Runar Schildt \& Johan Bargum: Hemkomsten [Homecoming], also in Finnish Kotiinpaluu 1976, 1977, 1979.

1977

IImari Turja: Jääkäri Ståhl [Jaeger Ståhl], Vaasan kt, [Vaasa City Th.], 1979.

1992

Esa Kirkkopelto: Pontikkatehdas [The Forest Distillery]. Ylioppilasteatteri. [Helsinki Student Theatre.]

Esa Kirkkopelto: Mahnovitshina. Ylioppilasteatteri. [Helsinki Student Theatre.]

1996

Heikki Ylikangas: Tie Tampereelle [The Road of Tampere], historical scholarship of 1993 adapted for stage by Harri Virtanen and Ritva Holmberg. TTT [Tampere Workers' Theatre].

1998

Ilpo Tuomarila: Hennalan torvisoittokunta [Hennala brass band]. Turun kt. [Turku City Th.]

2000

Jarl Hemmer \& Joachim Groth: En man och hans samvete [A Man and his Conscience], SvT [Swed. Th.]

2003

Leena Lander: Käsky [The Command]. Novel.

2006

Leena Lander: Käsky [The Command]. Stage adaptations by Seppo Parkkinen \& Juha Malmivaara. SKT [Fi. Nat.Th.]

Kjell Westö: Där vi en gång gått [Where We Once Walked]. Novel.

2007

Tytti Issakainen Vihan päivät 1918 [Days of hatred 1918.] Tampere Cathedral. 
2008

Kjell Westö \& Kari Heiskanen: Där vi en gång gått [Where We Once Walked]. HKT, [Helsinki City Th.]

Sovinnon päivä. [Day of Reconciliation.] $90^{\text {th }}$ memorial of the battle of Tampere, prod. by the Tampere City Museum.

Anneli Kanto: Veriruusut, [The Roses of Blood], Novel

2013

Fellmanin kenttä [Fellman's Field] performance-event arranged by Kaisa Salmi.

2017

Anneli Kanto \& Heini Tola: Erottaja 1917-1918, [The Divider-Street] Th. Avoimet ovet

Mikko Reitala: Suomen hauskin mies [The most hilarious man of Finland], Helsinki City Th.

Anneli Kanto: Lahtarit [The Slaughters], novel

2018

Sirpa Kähkönen \& Taru Mäkelä Vihan kevät Helsinki 1918. [ The Spring of Hatred, Helsinki 1918] Prod. Helsinki City Museum.

Anneli Kanto \& Lauri Maijala: Veriruusut [The Roses of Blood] KOM-teatteri

Anneli Kanto \& Sirkku Peltola: Tytöt 1918, [Girls 1918] based on Veriruusut [The Roses of Blood]. TTT [Tampere Workers' Theatre].

Anneli Kanto \& Sari Lillienstierna: Lahtarit [The Slaughters], Theatre group Sarin sakki.

Olli Kortekangas \& Tuomas Parkkinen: Veljeni vartija, [My Brother's Keeper]. Opera. Tampere-talo [Tampere-house.]

Tuomas Hoppu \& Anna-Elina Lyytikäinen: 1918 Teatteri Taistelussa; [1918 Theatre in the Battle]. Tampereen Teatteri, (TT, Theatre of Tampere) 